\title{
PENERAPAN METODE PENILAIAN BERBASIS PORTOFOLIO DALAM MENINGKATKAN PEMBELAJARAN BAHASA INDONESIA
}

\author{
Bagus Mahardika \\ Pascasarjana UIN Sunan Kalijaga Yogyakarta \\ Jl. Laksda Adisucipto, Caturtunggal, Kec. Depok, Kabupaten Sleman, Yogyakarta 55281 \\ E-mail: bagus.mahardika72@gmail.com
}

\begin{abstract}
Assessment is one of the important stages in the learning process of Indonesia because through the assessment of teachers to know the extent to which the learning objectives have been achieved. Assessment can be done through measurement (quantitative description) and / or through non-measurement (qualitative description). When teachers collect information on students' level of understanding through questions, observations, and assignments the teacher actually has conducted a non-measurement evaluation. The activity of the teacher is very useful in determining the level of mastery of students and in assessing the effectiveness of the learning process. Accurate information about student learning outcomes, interests and needs can only be obtained through effective assessment and assessment. The current assessment is a portfolio assessment that has many benefits for both teachers and students. Portfolio assessment is broader than assessment through tests, as with portfolios, teachers can follow cognitive development, attitudes, interests and student activities related to math. Thus, teachers can utilize the portfolio in improving the quality of learning which in turn will improve the quality of student learning outcomes.
\end{abstract}

Keywords: Method, Portfolio Assessment, Bahasa Indonesia.

\begin{abstract}
Abstrak
Penilaian merupakan salah satu tahapan yang penting dalam proses pembelajaran Bahasa Indonesiakarena melalui penilaian guru dapat mengetahui sejauh mana tujuan pembelajaran telah tercapai. Penilaian dapat dilakukan melalui pengukuran (deskripsi kuantitatif) dan/ atau melalui non-pengukuran (deskripsi kualitatif). Ketika guru mengumpulkan informasi mengenai tingkat pemahaman siswa melalui pertanyaan, observasi, dan pemberian tugas sebenarnya guru telah melakukan evaluasi non-pengukuran. Kegiatan guru tersebut sangat bermanfaat dalam menentukan tingkat penguasaan siswa dan dalam menilai keefektifan proses pembelajaran. Informasi yang akurat tentang hasil belajar, minat dan kebutuhan siswa hanya dapat diperoleh melalui asesmen dan penilaian yang efektif. Asesmen yang sedang berkembang saat ini adalah penilaian portofolio yang disinyalir memiliki banyak manfaat baik bagi guru maupun bagi siswa. Penilaian portofolio lebih luas dibandingkan penilaian melalui tes, karena dengan portofolio, guru dapat mengikuti perkembangan kognitif, sikap, minat dan berbagai kegiatan siswa berkaitan dengan matematika. Dengan demikian guru dapat memanfaatkan portofolio dalam meningkatkan mutu pembelajaran yang pada gilirannya akan meningkatkan mutu hasil belajar siswa.
\end{abstract}

Kata kunci: Metode, Penilaian Portofolio, Bahasa Indonesia. 


\section{Pendahuluan}

Penilaian merupakan bagaian yang terpenting dari proses belajar mengajar. Penilain merupakan suatu proses untuk menentukan nilai segala sesuatu. Penilaian berbeda dengan pengukuran (measurement), karena pengukuran lebih bersifat kuantitatif. Bahkan pengukuran merupakan instrumen untuk melakukan penilaian. Dengan penilaian, guru akan mengetahui perkembangan proses belajar, inteligensi, bakat khusus, minat, hubungan sosial, sikap, dan kepribadian peserta didik. ${ }^{1}$ Tidak ada proses belajar mengajar yang bebas dari penilaian dan juga tidak ada guru ataupun siswa yang dapat menghindar darinya. Sejak mulai karier sampai pensiun guru terus saja berurusan dengan penilain. ${ }^{2}$ Penilaian bertujuan untuk mengetahui efektifitas kegiatan pembelajaran. ${ }^{3}$ Jadi penilaian memang tidak terelakan kehadirannya.

Dalam proses belajar mengajar yang dinilai adalah siswa atau murid. Oleh karena sekolah mempunyai tugas untuk mendidik anak sebagai pribadi yang untuh, maka penilain tidak hanya terbatas pada status akademiknya saja, namun dalam tataran aplikasi dilapangan, guru secara langsung lebih banyak terlibat dalam mengukur dan menilai hasil belajar siswa khususnya prestasi akademiknya. ${ }^{4}$

Pendidikan dewasa ini semakin berkembang sehingga menuntut seorang guru harus memiliki berbagai kompetensi profesionalisme dan keterampilan sebagai seorang pengajar dan pendidik. Salah

1 Abdul Rachman Shaleh, Pendidikan Agama \& Pembangunan Watak Bangsa (Jakarta: PT Raja Grafindo Persada, 2010), 208-209.

2 Abin Syamsuddin Makmun, Psikologi Kependidikan Perangkat Sistem Pengajaran Modul (Bandung: PT Remaja Rosda Karya, 2012), 45.

3 Dedi Irwansyah, Meaningful Assessment for Writing at Islamic Universities, Pedagogy: Journal of English Language Teaching, 1, No 1 (Juni, 2013): 1

4 Nana Sujana, Penilaian Hasil Proses Belajar Mengajar (Bandung: PT Remaja Rosdakarya, 1989), 2. satu keterampilan yang harus dimiliki seorang guru adalah keterampilan untuk mengevaluasi dan assesmen (penilaian) terhadap peserta didiknya termasuk penilaian portofolio. Portofolio dapat diartikan sebagai kumpulan hasil belajar atau karya peserta didik yang menunjukkan usaha, perkembangan, prestasibelajar peserta didik dari waktu ke waktu dan dari satu mata pelajaran ke pelajaran yang lain. Dalam sebuah penelitian, Grenchik, O'Connor, dan Postelli (1999) menekankan bahwamengatur lingkungan atau kegiatan untuk memenuhi kebutuhan siswa belajar membantu siswa untukmeningkatkan tingkat motivasi mereka terhadap belajar.Dalam studi mereka, portofolio digunakan sebagai salah satualat untuk menyediakan lingkungan belajar yang memadai bagi siswa dan untuk menilai siswatanggung jawab dan motivasi untuk belajar. Portofolio dapat dilihat sebagai salah satu cara mengaturlingkungan belajar yang cocok untuksiswa. Bagaimana penilaian portofolio mampu memberikan efek kepada siswa dalam mengutarakan pertanyaan yang signifikan. Biggs (1999) menunjukkan bahwa portofolio, sebagai bentuk penilaian, mampumeningkatkan belajar siswa. ${ }^{5}$

Portofolioberfungsiuntukmengetahui perkembangan pengetahuan peserta didik dan kemampuan dalam mata pelajaran tertentu, serta pertumbuhan kemampuan peserta didik. Dalam prakteknya, portofolio dilandasi 4 pilar pendidikan, yaitu learning to do, learning to know, learning to be, learning to live together. Learning to do, agar peserta didik mampu berbuat untuk memperkaya pengalaman belajarnya dengan meningkatkan interaksi dengan lingkungan, sosial maupun budaya.

Learning to know, agar peserta didik dapat membangun pemahaman dan

5 Mentap Cakan dan Gulcan Mihladiz dkk, "How Portfolio Use Affects Students' Learning and Their Attitudes Toward 6 Th Grade Science Lesson," Journal of Educational Sciences 2, no. 2 (2010). 
pengetahuannya terhadap dunia sekitarnya. Learning to be, agar peserta didik mampu membangun pengetahuan dan kepercayaan dirinya. Learning to live together, agar peserta didik dapat berinteraksi dan membentuk kepribadiannya, memahami kemajemukkan dan melahirkan sikap-sikap positif dan toleran terhadap keanekaragaman dan perbedaan hidup. Kita dapat mengetahui berdasarkan pemaparan di atas bahwa penilaian portofolio penting untuk diketahui oleh seorang guru. Dengan demikian dari pemaparan permasalah diatas maka penulis tertarik melakukan penulisan Jurnaldengan judul "Penerapan Metode Penilaian Berbasis Portofolio Dalam Meningkatkan Pembelajaran Bahasa Indonesia"

Dari permasalahan di atas, penulis merumuskan ke dalam dua pertanyaan penelitian, yaitu 1) Bagaimana penerapan penilaian berbasis portofolio dalam meningkatkan pembelajaran bahasa Indonesia pada siswa? 2) Bagaiman pelaksanaan penilaian portofolio agar dapat meningkatkan prestasi belajar siswa pada mata pelajaran bahasa Indonesia?

\section{Pembahasan}

\section{Penilain Portofolio}

Portofolio telah muncul sebagai alat penilaian yang layak sejak tahun 1990-an, Portofolio menilai koleksi karya terbaik seorang pelajar, tidak hanya dokumen pembelajar kemajuan dari waktu ke waktu, tetapijuga mendorong siswa untuk menjadi lebih mandiridiarahkan, mengambil inisiatif untuk learning, membuat penilaian, dan berpartisipasi dalam evaluasi /pekerjaannya sendiri dan memecahkan masalah yang muncul. ${ }^{6}$

6 Salameh F. Obeiah dan Ruba Fahmi Bataineh, "The Effect of Portfolio -Based Assessment on Jordanian EFL Learner's Writing Performance," Bellaterra Journal of Teaching $\mathcal{E}$ Learning Language $\mathcal{E}$ Literature 9, no. 1 (Maret 2016).
Pengertian Portofolio secara etimologi, berasal dari dua kata, yaitu port (singkatan dari report) yang berarti laporan dan folio yang berarti penuh atau lengkap. Secara terminologi, Portofolio adalah kumpulan karya siswa yang disusun secara sistematis dan terorganisir sebagai hasil dari usaha pembelajaranyang telah dilakukannya dalam kurun waktu tertentu. Penilaian portofolio merupakan suatu konsep penilaian yang tidak asing lagi.

Portofolio berasal dari koleksi 'karya artis', mereka yang telah lama menggunakan penilaian ini untuk menunjukkan kompetensi. Dalam menanggapi perlu untuk praktek penilaian alternatif dan lebih otentik, portofolio telah menjadi alternatif metode penilaian tradisional. ${ }^{7}$ Ide menggunakan portofolio sebagai instrumen dalam penilaian berbasis kinerja bukanlah hal baru. Dari masa lalu untuk hadir, terutama pelukis, seniman,penulis, model dan fotografer telah dipamerkan keterampilan kejuruan dan diperoleh melalui portofolio. ${ }^{8}$

Penilaian portofolio disekolah dapat diperolehmelaluihasilkaryasiswa, gurudapat melihat perkembangan kemampuan siswa baik dalam aspek pengetahuan (kognitif), sikap (afektif) maupun keterampilan (psikomotorik) sebagai bahan penilaian. Hasil karya yang dihasilkan bisa hasil karya yang dikerjakan di dalam kelas atau bisa juga hasil kerja siswa yang dilakukan di luar kelas. Hasil karya siswa itu kemudian dinamakan evidence, melalui evidence inilah siswa dapat mendemonstrasikan unjuk kerja kepada orang lain baik tentang pengetahuan, sikap maupun keterampilan sesuai dengan tujuan

7 Ahmad Sharifi dan Jaleh Hassaskhah dkk, "The Role of Portfolio Assessment and Reflection on Process Writing," Journal Of Educational Sciences University of Guilan 3, no. 6 (2012).

8 Jeff J S Huang dan Stephen J H Yang, "Building an E-Portfolio Learning Model: Goal Orientation and Metacognitive Strategies," Management $\mathcal{E}$ E-Learning: An International Journal 4, no. 1 (2015). 
pembelajaran. ${ }^{9}$ Dewasa ini, model penilaian yang telah diterapkan secara nasional adalah Penilaian Berbasis Kelas/PBK (classroom-based assessment). Salah satu teknik pendekatannya yaitu dengan menggunakan portofolio. Teknik ini menjadi bagian integral dalam PBK daripada cara-cara tes tertulis (paper andpencil test) yang biasa dilakukan oleh guru. Secara praktik, penilaian berbasis portofolio tidak banyak membandingkan kemampuan hasil belajar seorang peserta didik dengan kemampuan hasil belajar teman-temannya, melainkan hal itu dibandingkan dengan kemampuan sebelumnya. ${ }^{10}$

Menurut para Ahli, portofolio memiliki beberapa pengertian. Ada yang memandang sebagai benda, dan ada pula yang memandang sebagai metode/teknik/ cara. Portofolio sebagai suatu wujud benda fisik, atau kumpulan suatu hasil (bukti) dari suatu kegiatan, atau bundelan, yakni kumpulan dokumentasi atau hasil pekerjaan seseorang (peserta didik) yang disimpan dalam suatu bundel. Misalnya, bundelan hasil kerja siswa mulai dari tes awal, tugastugas, catatan anekdot, piagam penghargaan, keterangan melaksanakan tugas terstruktur, sampai kepada tes akhir. Portofolio ini merupakan kumpulan karya terpilih dari seorang siswa atau sekelompok siswa. Istilah karya terpilih menunjukkan bahwa tidak semua karya siswa dapat dimasukkan ke dalam portofolio tersebut. Karya yang diambil adalah karya terbaik, karya yang paling penting dari pekerjaan siswa, yang bermakna bagi siswa, sesuai dengan tujuan pembelajaran atau kompetensi yang telah dirumuskan dalam tujuan pembelajaran.

Penilaian portofolio berbeda dengan pendekatan penilaian yang lain. Pendekatan penilaian portofolio adalah

9 Ahmad Munib, Pengantar Ilmu Pendidikan, (Semarang: UPT MKK UNNES, 2004), 29.

${ }_{10} \mathrm{M}$. Uzer Usman dan Lilis Setiawan, Upaya Optimalisasi Kegiatan Belajar Mengajar (Bandung: PT Remaja Rosdakarya, 1993), 120. suatu pendekatan penilaian yang bertujuan mengukur sejauhmana kemampuan peserta didik dalam mengkonstruksi dan merefleksi suatu pekerjaan/tugas atau karya melalui pengumpulan (collection) bahanbahan yang relevan dengan tujuan dan keinginan yang dikonstruksi oleh peserta didik, sehingga hasil konstruksi tersebut dapat dinilai dan dikomentari oleh guru dalam periode tertentu. Jadi, penilaian portofolio merupakan suatu pendekatan dalam penilaian kinerja peserta didik atau digunakan untuk menilai kinerja.

Kelebihan pendekatan portofolio adalah memberikan kesempatan kepada peserta didik untuk lebih banyak terlibat, dan siswa sendiri dapat dengan mudah mengontrol sejauhmana perkembangan kemampuan yang telah diperolehnya. Jadi, peserta didik akan mampu melakukan self-assessment. Keterampilan menemukan kelebihan dan kekurangannya sendiri, serta kemampuan untuk menggunakan kelebihan tersebut dalam mengatasi kelemahannya merupakan modal dasar penting dalam proses pembelajaran.

Penilaian portofolio merupakan proses yang berkelanjutan (yaitu, penilaian berkelanjutan), charting kemajuan siswa ke arah standar yang diharapkan di setiap keluar hasil belajar. Untuk masing-masing kandidat dalam mendapatkan keuntungan dari penilaian berkelanjutan, portofolio supervisor keharusan memiliki sesi review berkala untuk membahas penilaian dengan siswa dan memantau kemajuan siswa ke arah hasil belajar kurikulum. Davis, M.H dan Ponnamperuma, G.G. portofolio Penilaian'(P 280. JVME 2005). ${ }^{11}$ Dalam sistem penilaian portofolio, guru membuat fileuntuk masingmasing peserta didik, berisi kumpulan sistematis atas hasil prestasi belajar mereka

${ }^{11}$ Lahmer Mokhtaria, "The Use of Portfolio as an Assessment Tool," International Journal Of Scientific ELorraineTechnology Research 4, no. 7 (2015). 
selama mengikuti proses pendidikan. Di dalam file portofolio, guru mengumpulkan bukti fisik dan catatan prestasi siswa, seperti hasil ulangan, hasil tugas mandiri, serta hasil praktikum. Selain prestasi akademik, isi file juga dapat dielaborasi dengan lembar catatan prestasi non akademik, yakni rekaman profilepeserta didik yang meliputi aspek kerajinan, kerapihan, ketertiban, kejujuran, kemampuan kerjasama, sikap, solidaritas, toleransi, kedisiplinan, prestasi olah raga, kesenian, kepramukaan, dan lain-lain. ${ }^{12}$

Data yang terkumpul dari waktu ke waktu ini kemudian digunakan oleh guru untuk menilai dan melihat perkembangan kemampuan serta prestasi akademik siswa dalam periode tersebut. File portofolio sekaligus akan memberikan umpan balik (feed back), baik kepada guru maupun kepada peserta didik. Bagi guru, file yang berisi prestasi siswa ini akan memberikan masukan (input) untuk penilaian proses, terutama dalam memperbaiki strategi, metode dan manajemen pembelajaran di kelas. Melalui analisa file portofolio, guru dapat mengetahui potensi, karakter, kelebihan, dan kekurangan siswa. Bagi siswa, fileini dapat menjadi dasar pijakan mampu mengoreksi dan memperbaiki kelemahan serta kekurangannya dalam proses pembelajaran maupun penguasaannya tentang suatu pokok bahasan atau materi pelajaran tertentu.

Proses terjadinya umpan balik sangat dimungkinkan, karena dalam sistem penilaian portofolio, data yang terekam dalam file tidak hanya dikumpulkan saja kemudian selesai, namun akan dianalisis secara kolaboratif dengan melibatkan guru, peserta didik dan orang tua. Penilaian data melalui pembicaraan secara periodik dengan orang tua peserta didik merupakan progress reportyang akurat tentang kemajuan prestasi

12 Zainal Arifin, Evaluasi Pembelajaran (Bandung: PT Remaja Rosdakarya, 2009), 198. belajar peserta didik serta perkembangan kepribadiannya. ${ }^{13}$

Selain dapat dipergunakan untuk memantau perkembangan peserta didik serta mendiagnosa kesulitan belajar, penilaian portofolio juga sangat bermanfaat bagi guru untuk menilai kebutuhan (need), minat (interest), kemampuan akademik (abilities), dan karakteristik peserta didik secara perorangan. Hal tersebut penting, karena seharusnya dalam suatu sistem penilaian, eksistensi peserta didik secara perorangan tidak boleh dieliminasikan sebagaimana yang sering terjadi dalam tes standar seperti Ebtanas.

Portofolio menyangkut usaha-usaha yang dilakukan peserta didik, kemajuan dan prestasi yang dicapainya untuk suatu bidang studi/tema/topik tertentu dalam jangka waktu tertentu. Koleksi bahan menunjukkan cakupan dan tingkat partisipasi (keaktifan belajar). Adanya bahan-bahan yang benarbenar bermanfaat (meaningful) merupakan bukti refleksi bahwa peserta didik bertangungjawab atas kegiatan belajarnya, sekaligus terpupuk kesadarannya. Untuk melakukan perbaikan dan penyempurnaan atas cara-cara/kegiatan belajar yang ditempuhnya. ${ }^{14}$

Penilaian portofolio pada dasarnya adalah menilai karya-karya peserta didik berkaitan dengan mata pelajaran tertentu. Semua tugas yang dikerjakan peserta didik dikumpulkan, dan diakhir satu unit program pembelajaran diberikan penilaian. Dalam menilai dilakukan diskusi antara peserta didik dan guru menentukan skornya. ${ }^{15}$ Martini Jamaris mengungkapkan bahwa

${ }^{13}$ Arifin, 199.

14 Meng Kay Ling, "The Use of Academic Portfolio in the Learning and Assessment of Physics Students," Journal of Educational Sciences 3, no. 2 (2016).

15 Nazarudin, Manajemen Pembelajaran Implementasi Konsep, Karakteristik Dan Metodologi Pendidikan Agama Islam Di Sekolah Umum (Yogyakarta: Teras, 2007), 186. 
asesmen (penilaian) portofolio merupakan alat penilaian yang cocok untuk anak usia dini karena dapat menilai hasil belajar dari waktu ke waktu.Portofolio berbentuk berbagai sajian-sajian dan unjuk kerja atau bukti nyata dari hasil belajar anak. ${ }^{16}$

Penilaian portofolio berbeda dengan jenis penilaian lainnya. Penilaian portofolio adalah suatu pendekatan atau model penilaian yang bertujuan untuk mengukur kemampuan pesertadidikdalammembangun dan merefleksi suatu tugas melalui pengumpulan bahan-bahan yang relevan dengan tujuan dan keinginan yang dibangun oleh peserta didik, sehingga hasil pekerjaan tersebut dapat dinailai dan dikomentari oleh guru dalam periode tertentu. Jadi, penilaian portofolio merupakan suatu pendekatan dalam penilaian kinerja peserta didik.

Penilaian portofolio salah satu bentuk populer penilaian alternatif disebut penilaian portofolio(portfolioassessment)dapatdiartikan sebagai suatu kegiatan pengumpulan dan pengevaluasian sampel karya siswa dalam kurun waktu yang panjang. ${ }^{17}$ Guru dapat mengumpulkan karangan, proyek, dan bukti lain tentang fungsi siswa yang lebih tinggi dan menggunakan bukti ini untuk mengevaluasi kemajuan siswa dari waktu ke waktu. Misalnya, banyak guru meminta siswa menyimpan portofolio tulisan mereka yang memperlihatkan perkembangan karangan dari penulisan pertama hingga hasil akhir, seperti hasil belajar membuat catatan harian, laporan buku,karya seni, cetakan komputer, atau makalah yang memperlihatkan perkembangan penyelesaian.

Portofolio makin banyak disimpan ke dalam komputer untuk melengkapi berkas. Penilaian portofolio mempunyai kegunaan penting ketika guru ingin mengevaluasi

${ }^{16}$ Depdiknas, Kurikulum Berbasis Kelas(Penilaian Kelas) (Jakarta: Pusat Kurikulum Balitbangdiknas, 2002), 5.

17 Robert. E Salvin, Educational Psychology (Pearson Education.Inc, 2006), 208. siswa untuk memberi laporan kepada orang tua atau tujuan lain di sekolah. Jika digabungkan dengan penilaian yang diharuskan dan digunakan bersama rubik yang konsisten serta bersifat umum, portofolio yang memperlihatkan perbaikan dari waktu ke waktu dapat memberi bukti perubahan yang sangat kuat kepada orang tua dan siswa sendiri.

Penilaian portofolio bertujuan sebagai alat formatifmaupun sumatif. Portofolio sebagai alat formatif digunakan untuk memantau kemajuan peserta didik dari hari ke hari dan untuk mendorong peserta didik dalam merefleksi pembelajaran mereka sendiri. Portofolio seperti ini difokuskan pada proses perkembangan peserta didik dan digunakan untuk tujuan formatif dan diagnostik. Penilaian portofolio ditujukan juga untuk penilaian sumatif pada akhir semester atau akhir tahun pelajaran. Hasil penilaian portofolio sebagai alat sumatif ini dapat digunakan untuk mengisi angka rapor peserta didik, yang menunjukkan prestasi peserta didik dalam mata pelajaran tertentu.

Portofolio jugadapat berperan dalam menilai efektivitaskursus, kurikulum, dan lembaga bahkan Portfolio juga digunakan untuk mendukung dan mendokumentasikan pengembangan pribadi, profesional, dan intelektual siswa. ${ }^{18}$ Fungsi dari penilian portofolio lainnya ialah Portofolio digital elektronik Platform yang menyimpan konten visual dan auditori (termasuk teks, images, video, dan suara) untuk menunjukkan kompetensi dan refleksi dalam bidang pengetahuan untukguru,kolega, profesional, atau komunitas. Platform ini tidak hanya sarana belajar untukmendukung berbagai proses pedagogis dan penilaian purpos, tetapi juga menyangkut ruang virtual di

${ }^{18}$ Catherine A Buyarski dan Cynthia M Landis, "Using an EPortfolio to Assess the Outcomes of a First-Year Seminar: Student Narrative and Authentic Assessment," International Journal Of Indiana University Bloomington 4, no. 1 (2004): 12. 
webberdasarkan lingkungan. Banyak peneliti telah menggambarkan "Portofolio. ${ }^{19}$

Pada hakikatnya, tujuan penilaian portofolio adalah untuk memberikan informasi kepada orang tua tentang perkembangan peserta didik secara lengkap dengan dukungan data dan dokumen yang akurat. Rapor merupakan bentuk laporan prestasi peserta didik dalam belajar dalam kurun waktu tertentu. Portofolio merupakan lampiran dari rapor, dengan demikian rapor tetap harus dibuat. Tujuan portofolio ditetapkan oleh apa yang harus dikerjakan dan siapa yang akan menggunakan penilaian portofolio tersebut. Fakta yang paling penting dalam portofolio adalah digunakannya penilaian tertulis (paper and pencil assessment), project, produck, dan catatan kemampuan (records of performance). Penilaian portofolio dapat digunakan untuk mencapai beberapa tujuan, antara lain :

a. Menghargai perkembangan yang dialami peserta didik.

b. Mendokumentasikan proses pembelajaran yang berlangsung.

c. Memberi perhatian pada prestasi kerja peserta didik yang terbaik.

d. Merefleksikan kesanggupan mengambil resiko dan melakukan eksperimentasi.

e. Meningkatkan efektifitas proses pengajaran.

f. Bertukar informasi dengan orang tua/ wali peserta didik dan guru lain.

g. Membina dan mempercepat pertumbuhan konsep diri positif pada peserta didik.

h. Meningkatkan kemampuan melakukan refleksi diri.

i. Membantu peserta didik dalam merumuskan tujuan. ${ }^{20}$

${ }^{19}$ Uluslararası Sosyal dan Ara tırmalar Dergisi, "The Effects of Portfolio Assessment on Reading, Listening And Writing Skills of Secondary School Prep Class Students," The Journal of International Social Research 2, no. 9 (2009).

${ }^{20}$ Sumarna Surapranata dan M. Hatta, Penialain Portofolio implementasi Kurikulum (Bandung: PT Remaja Rosdakarya, 2004), 76.

\section{Fungsi Penilaian Portofolio}

a. Portofolio sebagai sumber informasi bagi guru dan orang tua untuk mengetahui pertumbuhan dan perkembangan kemampuan peserta didik, tanggung jawab dalam belajar, perluasan dimensi belajar, dan pembaharuan proses pembelajaran

b. Portofolio sebagai alat pengajaran merupakankomponenkurikulum, karena potofolio mengharuskan peserta didik untuk mengoleksi dan menunjukkan hasil kerja mereka.

c. Portofolio sebagai alat penilaian otentik (authentic assessment).

d. Portofolio sebagai sumber informasi bagi siswa untuk melakukan self-assessment.

\section{Penilaian Portofolio}

Direktorat PLP-Ditjen DikdasmenDepdiknas mengemukakan bahwa pendekatan penilaian portofolio dapat digunakan untuk:

a. Memperlihatkan perkembangan pemikiran atau pemahaman siswa pada periode waktu tertentu. Misal, mulai dari kegiatan pencatatan (pembuatan catatan), mengkopi bahan, membuat kerangka awal, draft kasar, kritik terstruktur, dan finalisasi paper.

b. Menunjukkan suatu pemahaman dari beberapa konsep, topik, dan isu yang diberikan.

c. Mendemonstrasikan perbedaan bakat. Misalnya, melihat kemampuan menulis, perbedaan kemampuan mendengarkan, mengungkapkan secara lisan, dan lainlain.

d. Mendemonstrasikan kemampuan untuk memproduksi atau mengkreasi suatu pekerjaan baru secara orisinal.

a. Mendokumentasikan kegiatan selama periode waktu tertentu.

b. Mendemonstrasikan kemampuan menampilkan suatu karya seni.

c. Mendemonstrasikan kemampuan mengintegrasikan teori dan praktek. 
d. Merefleksikan nilai-nilai individual atau pandangan dunia secara lebih luas. $^{21}$

\section{Prinsip-prinsip Penilaian Portofolio}

Dalam penilaian portofolio harus terjadi interaksi multi arah, yaitu dari guru ke siswa, dari siswa ke guru, dan dari siswa ke siswa. Depdiknas mengemukakan bahwa “pelaksanaan penilaian portofoliohendaknya memperhatikan prinsip-prinsip mutual trust, confidentiality, joint ownership, satisfaction, and relevance". ${ }^{22}$ Antara lain pembahasannya sebagai berikut:

a. Mutual trust (saling mempercayai), artinya jangan ada saling mencurigai antara guru dengan siswa maupun siswa dengan siswa. Mereka harus sama-sama saling percaya, saling membutuhkan, saling membantu, terbuka, jujur, dan adil, sehingga dapat membangun suasana penilaian yang kondusif.

b. Confidentiality (kerahasiaan bersama), artinya semua hasil pekerjaan peserta didik dan dokumen yang ada, baik perorangan maupun kelompok, harus dijaga kerahasiaannya, tidak boleh diberikan atau diperlihatkan kepada siapapun sebelum diadakan pameran. Hal ini dimaksudkan agar peserta didik yang mempunyai kelemahan tidak merasa dipermalukan.

c. Joint Ownership (milik bersama), artinya semua hasil pekerjaan peserta didik dan dokumen yang ada harus menjadi milik bersama antara guru dan peserta didik, karena itu harus dijaga bersama, baik penyimpanannya maupun penempatannya.

d. Satisfaction (kepuasan), artinya semua dokumen dalam rangka pencapaian standar kompetensi, kompetensi dasar dan indikator harus dapat memuaskan

${ }^{21}$ Direktorat PLP-Ditjen DikdasmenDepdiknas.op.cit 123

${ }^{22}$ Depdiknas.op.cit 124 semua pihak, baik guru maupun siswa, karena dokumen tersebut merupakan bukti karya terbaik peserta didik sebagai hasil pembinaan guru.

e. Relevance (kesesuaian), artinya dokumen yang ada harus sesuai dengan kompetensi yang diharapkan. Di samping prinsip-prinsip tersebut di atas, Sumarna Surapranata dan Muhammad Hatta menambahkan tiga prinsip, yaitu "penciptaan budaya mengajar, refleksi bersama, serta proses dan hasil". Penilaian portofolio hanya dapat dilakukan jika pengajarannyapun menggunakan pendekatan portofolio. Penilaian portofolio akan efektif jika pengajarannya menuntut peserta didik untuk menunjukkan kemampuan yang nyata dan menggammbarkan pengembangan aspek pengetahuan, keterampilan, sikap dan nilai pada taraf yang lebih tinggi. ${ }^{23}$

f. Prinsip Penilaian portofolio yang lain adalah memberikan kesempatan kepada peserta didik untuk melakukan refleksi bersama-sama, dimana peserta didik dapat merefleksikan tentang proses berpikir mereka sendiri, kemampuan pemahaman mereka sendiri, pemecahan masalah, dan pengambilan keputusan. Tidak hanya itu Penilaian portofolio harus menilai proses belajar peserta didik, seperti: catatan perilaku harian, sikap belajar, antusias tidaknya dalam mengikuti pelajaran, dan sebagainya. Penilaian portofolio juga harus menilai hasil akhir suatu tugas yang diberikan oleh guru.

\section{Karakteristik penilaian protofolio}

Menurut Barton dan Collins dalam S.Surapranata dan M.Hatta (2004) terdapat beberapa karakteristik esensial penilaian portofolio, yaitu multisumber, autentik, dinamis, eksplisit, integrasi, kepemilikan, 
dan beragam tujuan. ${ }^{24}$

\section{Kelebihan dan Kelemahan Penilaian Portofolio}

Setiap konsep atau model penilaian tentu ada kelebihan dan kekurangannya. Begitu juga dengan model penilaian portofolio. Kelebihan model penilaian portofolio, antara lain sebagai berikut:

a. Dapat melihat pertumbuhandan perkembangan kemampuan peserta didik dari waktu kewaktu berdasarkan feedback dan refleksi diri.

b. Membantu guru melakukan penilaian secara aktif, objektif, transparan dan dapat dipertanggung jawabkan tanpa mengurangi kreatifitas peserta didik dikelas.

c. Mengajak peserta didik untuk belajar bertanggung jawab terhadap apa yang telah mereka kerjakan, baik dikelas maupun diluar kelas dalam rangka implementasi program pembelajaran.

d. Meningkatkan peran peserta didik secara aktif dalam kegiatan pembelajaran dan penilaian serta pendekatan penilaian yang memungkinkan guru dan siswa untuk berinteraksi dalam mengajar/ belajarproses. Salah satu keuntungan menggunakan kinerja dan penilaian portofolio dengan bahasasiswa minoritas adalah bahwa penilaian dapat dilakukan dalam bahasa keseharian siswa ketika menggunakan bahasa sebagai sarana berkomunikasi. ${ }^{25}$

e. Memberi kesempatan kepada peserta didik untuk meningkatkan kemampuan mereka.

f. Membantu guru mengklarifikasi dan mengidentifikasi program pembelajaran.

g. Terlibatnya berbagai pihak, seperti

${ }^{24}$ Arifin, 204.

25 Lorraine Valdez Pierce dan J Michael O'Malley, "Performance And Portfolio Assessment For Language Minority Students," Journal Of NCBE Program Information Guide Series, no. 9 (1992). orang tua, guru, komite sekolah, dan masyarakat lainnya dalam melihat pencapaian kemampuan peserta didik.

h. Memungkinkan peserta didik melakukan penilaian diri (self-assesment) refleksi, dan mengembangkan kemampuan berpikir kritis. (critical thinking)

i. Memungkinkan guru melakukan penialain secara fleksibel, tetapi tetap mengacu pada kompetensi dasar dan indikator terhadap hasil belajaryang ditentukan.

j. Guru dan peserta didik sama-sama bertanggung jawab untuk merancang dan menilai kemampuan belajar.

Adapun kelemahan penilaian portofolio adalah sebagai berikut:

a. Memerlukan waktu dan kerja ekstra.

b. Penilaian portofolio dianggap kurang reliable dibandingkan dengan bentuk penilaian yang lain.

c. Ada kecenderungan guru hanya memperhatikan pencapain akhir sehingga proses penilaian kurang mendapat perhatian.

d. Jika guru melaksanakan proses pembelajaran yang bersifat teacheroriented, kemungkinan besar inisiatif dan kreativitas peserta didikakan terbelenggu sehingga penilaian portofolio tidak dapat dilaksanakan dengan baik.

e. Orang tua peserta didik sering berfikir skeptic karna laporan hasil belajar anaknya tidak berbentuk angka.

f. Penialain portofolio masih relative baru sehingga banyak guru orang tua dan peserta didik yang belum mengetahui dan memahaminya.

g. Tidak tersedianya kriteria penilaian yang jelas.

h. Analisis terhadap penilaian portofolio agak sulit dilakukan sebagai akibat dikuranginya penggunaan angka.

i. Sulit dilakukan terutama menghadapi ujian dalam skala nasional.

j. Dapat menjebak peserta didik jika 
terlalu sering menggunakan format yang lengkap dan detail. ${ }^{26}$

\section{Jenis Penilaian Portofolio}

Apabila dilihat dari jumlah peserta didik, maka penilaian portofolio dapat dibagi menjadi dua jenis, yaitu portofolio perorangan dan portofolio kelompok. Menurut Cole, Ryan, and Kick (1995) portofolio dapat dibagi dua jenis, yaitu "portofolio produk dan portofolio proses".

\section{a. Portofolio Proses}

Jenis portofolio proses menunjukkan tahapan belajar dan menyajikan catatan perkembangan peserta didik dari waktu ke waktu. Portofolio proses menunjukkan kegiatan pembelajaran untuk mencapai standar kompetensi, kompetensi dasar, dan sekumpulan indikator yang dituntut oleh kurikulum, serta menunjukkan semua hasil dari awal sampai dengan akhir dalam kurun waktu tertentu. Guru menggunakan portofolio proses untuk menolong peserta didik mengidentifikasi tujuan pembelajaran, perkembangan hasil belajar dari waktu ke waktu, dan menunjukkan pencapaian hasil belajar. Pendekatan ini lebih menekankan pada bagaimana peserta didik belajar, berkreasi, termasuk mulai dari draft awal, bagaimana proses awal itu terjadi, dan tentunya sepanjang peserta didik dinilai. Salah satu bentuk portofolio proses adalah portofoliokerja(working portfolio)yaitu bentuk yang digunakan untuk memantau kemajuan dan menilai peserta didik dalam mengelola kegiatan belajar mereka sendiri. Peserta didik mengumpulkan semua hasil kerja termasuk coretan-coretan (sketsa), buram, catatan, kumpulan untuk rangsangan, buram setengah jadi, dan pekerjaan yang sudah selesai.

Portofolio kerja bermanfaat untuk memberikan informasi bagaimana peserta didik mengorganisasikan dan mengelola

\footnotetext{
${ }^{26}$ Arifin, Evaluasi Pembelajaran, 206.
}

kerja, merefleksi dari pencapaiannya, dan menetapkan tujuan dan arahan. Informasi ini dapat digunakan untuk diskusi antara peserta didik dengan guru. Melalui portofolio kerja ini, guru dapat membantu peserta didik mengidentifikasi kekuatan dan kelemahan masing-masing.

Informasi ini dapat digunakan untuk memperbaiki cara belajar siswa. Keberhasilan portofolio kerja bergantung kepada kemampuan untuk merefleksikan dan mendokumentasikan kemajuan proses pembelajaran. Dalam portofolio kerja yang dinilai adalah cara kerja (pengorganisasian) dan hasil kerja. Adapun kriterianya antara lain :

1) Adakah pembagian kerja diantara anggota kelompok?

2) Apakah masing-masing anggota bekerja telah sesuai dengan tugasnya?

3) Berapa besar kontribusi kerja para anggota kelompok terhadap hasil yang dicapai kelompok?

4) Adakah bukti tanggung jawab bersama?

5) Apakah kelengkapan data yang diperoleh telah sesuai dengan tugas anggota kelompok masing-masing?

6) Apakah informasi yang diperoleh akurat?

7) Apakah portofolio telah disusun dengan baik?

\section{b. Portofolio produk}

Jenis penilaian portofolio ini hanya menekankan pada penguasaan (materi) dari tugas yang dituntut dalam standar kompetensi, kompetensi dasar, dan sekumpulan indikator pencapaian hasil belajar, serta hanya menunjukkan evidence yang paling baik, tanpa memperhatikan bagaimana dan kapan evidence tersebut diperoleh. Contoh portofolio produk adalah portofolio tampilan (show portfolio) dan portofolio dokumentasi (documentary 
portfolio). ${ }^{27}$ Dalam penilaian protofolio produk atau dapat juga disebut penilaian kinerja ini dapat dikembangkan dan diaplikasikan misalnya dalam memberikan muatan ketrampilan pada siswa, maka siswa dalam mengaplikasikannya dengan beragam praktik kinerja seperti keterampilan memanen sayuran, merawat tanaman, dan mengemas/mengolah menjadi produk yang layak jual. ${ }^{28}$

\section{c. Portofolio Tampilan}

Portofolio bentuk ini merupakan sekumpulan hasil karya peserta didik atau dokumen terseleksi yang dipersiapkan untuk ditampilkan kepada umum. Misalnya, mempertanggungjawabkan suatu proyek, menyelenggarakan pameran, atau mempertahankan suatu konsep. Bentukinibiasanya digunakan untuk tujuan pertanggungjawaban (accountability). Aspek yang dinilai dalam bentuk ini adalah:

1) Signifikansi materi: apakah materi yang dipilih benar-benar merupakan materi yang penting dan bermakna untuk diketahuidandipecahkan? atau seberapa besar tingkat kebermaknaan informasi yang dipilih berkaitan dengan topik yang dibahasnya?

2) Pemahaman: seberapa baik tingkat pemahaman siswa terhadap hakikat dan lingkup masalah, kebijakan, atau langkah-langkah yang dirumuskan?

3) Argumentasi: apakah siswa atau kelompok siswa dalam mempertahankan argumentasinya sudah cukup memadai?

4) Responsifness

(kemampuan

${ }_{27}$ Cakan dan Mihladiz, "How Portfolio Use Affects Students' Learning and Their Attitudes Toward 6 Th Grade Science Lesson."

28 Wendy Kicken, Saskia Brand-Gruwel, dan Jeroen J. G, dkk, "Design and Evaluation of a Development Portfolio: How to Improve Students' Self-Directed Learning Skills," International Journal Of Educational Technology Expertise Centre and Netherl ands Laboratory for Lifelong Learning Open University of the Netherlands 4, no. 2 (2010). memberikan respon): seberapa besar tingkat kesesuaian antara respon yang diberikan dengan pertanyaan?

5) Kerjasamakelompok: apakah anggota kelompok turut berpartisipasi dalam penyajian? Adakah bukti yang menunjukkan tanggung jawab bersama? Apakah para penyaji menghargai pendapat orang lain? Adakah kekompakan kerja diantara para anggota kelompok?

\section{d. Portofolio Dokumen}

Portofolio dokumen menyediakan informasi baik proses maupun produk yang dihasilkan oleh peserta didik. Model portofolio ini sangat bermanfaat bagi peserta didik dan orang tua untuk mengetahui kemajuan hasil belajar, kelebihan dan kekurangan dalam belajar secara perorangan. Berdasarkan dokumen ini, baik peserta didik maupun guru dapat melihat:

1) Proses apa yang telah diikuti?

2) Kerja apa yang telah dilakukan?

3) Dokumen apa yang telah dihasilkan?

4) Apakah hal-hal pokok telah terdokumentasikan?

5) Apakah dokumen disusun berdasarkan sumber-sumber data masing-masing?

6) Apakah dokumen berkaitan dengan yang akan disajikan?

7) Standar atau kompetensi mana yang telah dicapai sampai pada pekerjaan terakhir?

Indikator untuk penilaian dokumen itu antara lain: kelengkapan, kejelasan, akurasi informasi yang didapat, dukungan data, kebermaknaan data grafis, dan kualifikasi dokumen.

\section{Kesimpulan}

Dari pembahasan diatas dapat diambil kesimpulan bahwa Penilaian Portofolio dapat diartikan sebagai kumpulan karya siswa yang di susun secara sistematis 
secara terorganisir sebagai hasil dari usaha pembelajaran yang telah dilakukanya dalam kurun waktu tertentu.Penilaian portofolio bertujuan sebagai alat formatif maupun sumatif. Portofolio sebagai alat formatif digunakan untuk memantau kemajuan peserta didik dari hari kehari dan untuk mendorong peserta didik dalam merefleksi pembelajaran mereka sendiri.

Portofolio digunakan sebagai alat pengajaran dan juga sebagai alat penilaian. Penilaian portofolio mengharuskan peserta didik untuk mengkoleksi dan menunjukkan hasil kerja mereka. Dalam hal ini penilaian portofolio dapat dianggap sebagai salah satu alat pengajaran yang merupakan komponen kurikulum. Portofolio memiliki kelebihan dalam beberapa hal, terutama lebih objektif dilihat dari prestasi hasil kerja peserta didik yang sesungguhnya, lebih terbuka dimana peserta didik ikut serta menilai pekerjaan yang dilakukannya, dan secara langsung berhubungan dengan proses kegiatan pembelajaran.

\section{Daftar Pustaka}

Arifin,Zainal.EvaluasiPembelajaran.Bandung: PT Remaja Rosdakarya, 2009.

Buyarski, Catherine A, dan Cynthia M Landis. “Using an EPortfolio to Assess the Outcomes of a First-Year Seminar: Student Narrative and Authentic Assessment." International Journal of Indiana University Bloomington 4, no. 1 (2004): 12.

Cakan, Mentap, dan Gulcan Mihladiz dkk. "How Portfolio Use Affects Students' Learning and Their Attitudes Toward 6 Th Grade Science Lesson." Journal of Educational Sciences 2, no. 2 (2010).

Depdiknas. Kurikulum Berbasis Kelas(Penilaian Kelas). Jakarta: Pusat Kurikulum Balitbangdiknas, 2002.

Huang, Jeff J S, dan Stephen J H Yang.
"Building an E-Portfolio Learning Model: Goal Orientation and Metacognitive Strategies." Management \& E-Learning: An International Journal 4, no. 1 (2015).

Irwansyah, Dedi. "Meaningful Assessment for Writing at Islamic Universities". Pedagogy: Journal of English Language Teaching, 1, no 1 (2013)

Ling, Meng Kay. "The Use of Academic Portfolio in the Learning and Assessment of Physics Students." Journal of Educational Sciences 3, no. 2 (2016).

Makmun, Abin Syamsuddin. Psikologi Kependidikan Perangkat Sistem Pengajaran Modul. Bandung: PT Remaja Rosda Karya, 2012.

Mokhtaria, Lahmer. "The Use of Portfolio as an Assessment Tool." International Journal of Scientific ELorraineTechnology Research 4, no. 7 (2015).

Munib, Ahmad. Pengantar Ilmu Pendidikan, Semarang: UPT MKK UNNES, 2004.

Nazarudin. Manajemen Pembelajaran Implementasi Konsep, Karakteristik Dan Metodologi Pendidikan Agama Islam Di Sekolah Umum. Yogyakarta: Teras, 2007.

Obeiah, Salameh F., dan Ruba Fahmi Bataineh. "The Effect of Portfolio -Based Assessment on Jordanian EFL Learner's Writing Performance." Bellaterra Journal of Teaching $\mathcal{E}$ Learning Language \& Literature 9, no. 1 (Maret 2016).

Pierce, Lorraine Valdez, dan J Michael O’Malley. “PerformanceAnd Portfolio Assessment For Language Minority Students." Journal Of NCBE Program Information Guide Series, no. 9 (1992).

Salvin, Robert. E. Educational Psychology. 
Pearson Education.Inc, 2006.

Shaleh, Abdul Rachman. Pendidikan Agama \& Pembangunan Watak Bangsa. Jakarta: PT Raja Grafindo Persada, 2010.

Sharifi, Ahmad dan Jaleh Hassaskhah dkk. "The Role of Portfolio Assessment and Reflection on Process Writing." Journal of Educational Sciences University of Guilan 3, no. 6 (2012).

Sosyal, Uluslararası, dan Ara tırmalar Dergisi. "The Effects of Portfolio Assessment on Reading, Listening And Writing Skills of Secondary School Prep Class Students." The Journal of International Social Research 2, no. 9 (2009).

Sujana, Nana. Penilaian Hasil Proses Belajar Mengajar. Bandung: PT Remaja Rosdakarya, 1989.

Surapranata, Sumarna, dan M. Hatta. Penialain Portofolio implementasi Kurikulum. Bandung: PT Remaja Rosdakarya, 2004.

Usman, M. Uzer, dan Lilis Setiawan. Upaya Optimalisasi Kegiatan Belajar Mengajar. Bandung: PT Remaja Rosdakarya, 1993.

Wendy Kicken, Saskia Brand-Gruwel, dan Jeroen J. G, dkk. "Design and Evaluation of a Development Portfolio: How to Improve Students' Self-Directed Learning Skills." International Journal of Educational Technology Expertise Centre and Netherl ands Laboratory for Lifelong Learning Open University of the Netherlands 4, no. 2 (2010). 
46| Ilementirly Vol. 4 Edisi Januari-Juni 2018

halaman ini bukan sengaja untuk dikosongkan 